\title{
Effects of melatonin on photosynthesis and soybean seed growth during grain filling under drought stress
}

\author{
J.N. ZOU", X.J. JIN", Y.X. ZHANG+, C.Y. REN, M.C. ZHANG, and M.X. WANG \\ Heilongjiang Bayi Agricultural University, College of Agriculture, Daqing, 163319 Heilongjiang, China
}

\begin{abstract}
We studied the effects of melatonin on soybean photosynthesis and seed growth at different developmental stages under drought stress induced by polyethylene glycol in the growth medium. Experimental groups were supplied with a normal nutrient solution after seven days of continuous treatment; overall, five treatments were completed when the early maturity stage was reached. Under normal water supply, melatonin supplementation had no significant effect on the photosynthetic characteristics or soybean seed growth. However, drought stress reduced leaf relative water content, chlorophyll content, and relative photosynthetic gas-exchange parameters, while it increased a leaf content of osmoregulatory substances, antioxidant-related enzyme activities, and seed growth-related indicators. Compared to the drought-stressed group, the melatonin treatment under drought stress improved the above indicators; specifically, melatonin effectively increased the photosynthetic rate, 100-seed mass, and total seed mass per plant. All the effects were most significant during the first seven days after the early seed-filling stage.
\end{abstract}

Additional key words: catalase; malondialdehyde; proline; superoxide dismutase; water-use efficiency.

\section{Introduction}

Soybean (Glycine max [L.] Merr.) is one of major oil crops in the world and has a high economic and social value (Manavalan et al. 2009). In turn, drought is one of the main abiotic stress conditions that limit growth and yield potential, resulting in up to $40 \%$ reduction in soybean production (Specht et al. 1999). The sustainability of soybean production might be severely threatened by the continuous drought stress predicted for many regions of the world (Dai 2013, Foyer et al. 2016). Drought stress may lead to lowered relative water content (RWC) in soybean leaves, along with reduced stomatal conductance, photosynthetic and transpiration rates; concomitantly, dry matter accumulation might decrease by as much as 30\% (Ommen et al. 1999). Grain filling is a key stage in the development and yield formation of the soybean crop; simultaneously, it is the most complex metabolic stage for carbon and nitrogen assimilation and transportation. Thus, at this stage, drought stress inevitably has an adverse effect on the formation and transport of assimilation products, resulting in a reduced yield (Getachew 2014). During grain filling, recently produced, as well as stored assimilated photosynthetic products are continuously transported from source tissues (i.e., the leaves and storage organs) to sink tissues, i.e., the seeds (Westgate and Peterson 1993). During this process, the physiological activities of the plant gradually slow down until maturity is reached and seed development is completed. Furthermore, during the period of seed development, drought stress could have a variety of effects on the photosynthetic characteristics of soybean plants at different metabolic levels.

Melatonin is a plant growth regulator that has been shown to alleviate abiotic stress, such as high/low temperature, excess salinity, drought, and senescence. Melatonin reportedly participates in various developmental and regulatory processes in plants, including the promotion of root establishment and lateral root development (Zhang et al. 2013), the regulation of circadian rhythms, maintenance of cell redox balance, the regulation of fruit ripening, protection of chloroplasts (Lei et al. 2013, Sun et al. 2014), the regulation of leaf senescence, and the removal of reactive oxygen species (ROS) (Shi et al. 2015, Gao et al. 2016). Further, studies have shown that melatonin displays the same functions as auxin in plant growth regulation, i.e., it promotes growth at low concentrations,

\section{Received 5 July 2018, accepted 30 November 2018.}

${ }^{+}$Corresponding author: phone: + 86 459-6819122, e-mail: zyx 1xy@126.com

Abbreviations: APX - ascorbate peroxidase; CAT - catalase; $\overline{\mathrm{Chl}}$ - chlorophyll; $C_{\mathrm{i}}$ - intercellular $\mathrm{CO}_{2}$ concentration; DM - dry mass; $E$ - transpiration rate; FM - fresh mass; $g_{\mathrm{s}}$ - stomatal conductance; $\mathrm{L}_{\mathrm{s}}$ - stomatal limitation; MDA - malondialdehyde; $\mathrm{PEG}-$ polyethylene glycol; $P_{\mathrm{N}}$ - net photosynthetic rate; POD - peroxidase; ROS - reactive oxygen species; RWC - relative water content; SOD - superoxide dismutase; TM - turgid mass; WUE - water-use efficiency $\left(=P_{\mathrm{N}} / E\right)$.

Acknowledgements: This study was supported by the National Natural Science Foundation (No. 31401332, No. 31371560), the China Agriculture Research System (CARS-04-01A), the Natural Science Foundation of Heilongjiang Province of China (C2017049), the National Key Technology R\&D Program (2014BAD11B01-02), the Key Project of Crop Science in Heilongjiang Bayi Agricultural University of China (ZWXQDJ-4), and the project of the General Administration of Agriculture and Reclamation in Heilongjiang Province of China (HNK135-02-06).

\#These authors contributed equally to this work. 
whereas it inhibits the growth at high concentrations (Chen et al. 2009). Cucumber seedlings treated with $100 \mu \mathrm{mol}\left(\right.$ melatonin) $\mathrm{L}^{-1}$ improved their photosynthetic efficiency under adverse conditions, while melatonin alleviated the decrease in chlorophyll $(\mathrm{Chl})$ and increased the activity of antioxidant enzymes (Zhang et al. 2013). Spraying melatonin on apple leaves under drought stress delayed leaf senescence, increased leaf photosynthetic efficiency and carbon assimilation, enhanced antioxidant metabolism, and removed excess ROS (Wang et al. 2013). Pretreatment with melatonin improved photosynthetic and antioxidant capacity of maize under drought stress (Ye et al. 2016). Spraying $100 \mathrm{mg}$ (melatonin) $\mathrm{L}^{-1}$ solution on young grapefruit can induce the accumulation of endogenous melatonin and promote fruit growth (Meng et al. 2014). Pretreatment of soybean seeds (Glycine max) with $50 \mu \mathrm{mol}\left(\right.$ melatonin) $\mathrm{L}^{-1}$ under salt and drought stress conditions has been shown to elevate the expression of genes related to photosynthetic metabolism, increasing the growth and yield of soybean plants (Wei et al. 2014). Numerous studies have confirmed that melatonin can effectively increase the antioxidant capacity of crops and promote growth under abiotic stress. We believe that melatonin might improve soybean growth, promote seed development, and increase yield due a variety of physiological regulatory effects that have been confirmed. However, little is known about the regulatory effects of melatonin on photosynthetic characteristics, seed development during the seed-filling stage and soybean yield formation under drought stress. Therefore, in the present study, polyethylene glycol (PEG) was used to induce drought stress and exogenous melatonin was added at different stages of the seed development. This experimental scheme allowed us to analyze systematically the effects of melatonin underlying growth and yield restoration upon its application.

\section{Materials and methods}

Study site: The present study was conducted between May and October in 2017 at the experimental base of the National Engineering and Technology Research Center for Grains in the High-tech Zone, Daqing City, Heilongjiang Province, China $\left(46^{\circ} 39^{\prime} \mathrm{N}, 124^{\circ} 51^{\prime} \mathrm{E}\right)$, located in the north temperate continental monsoon climate zone, with an annual average accumulated temperature of $2689^{\circ} \mathrm{C}$, an average summer daily temperature of $23.6^{\circ} \mathrm{C}$, and an average day/night temperature difference of $8^{\circ} \mathrm{C}$.

Plant material: Uniform soybean (Glycine max [L.] Merr., cv. Suinong 26) seeds were manually selected, sterilized with $5 \%$ sodium hypochlorite, and then rinsed with distilled water and placed in an incubator at $22^{\circ} \mathrm{C}$ for germination. Uniform sprouts, $1 \mathrm{~cm}$ in length, were selected and soaked for $30 \mathrm{~min}$ in a rhizobium suspension (optical density $0.8-1.0$ ) for inoculation. Next, inoculated soybean sprouts were transferred to plastic pots filled with river sand.

Plant culture: Sand culture was used to cultivate the soybean plants. The sand used was fine river sand; it was first screened for large stones and plant residues, which were removed. Next, the sand was rinsed with tap water until no turbidity was observed and then it was rinsed three times with distilled water. The size of the plastic bucket was $33 \times 26 \mathrm{~cm}$; six 1-cm holes were drilled in the bottom of each bucket and gauze was placed over the holes before the buckets were filled with the sand. The cultivation system included: (1) plastic buckets and sand; (2) water pumps; (3) water pipes and sprinklers; and (4) water tanks. The plastic buckets and sand provided the substrate for soybean plant growth, and a circulatory system was constructed with the water pumps, water tanks, water pipes, and sprinklers. A nutrient solution was pumped into the system once a week from 06:00 to 09:00 h (Fig. 1).

Distilled water was supplied to the seeds and soybean seedlings before the cotyledon stage, and $500 \mathrm{ml}$ of nutrient solution was supplied after the cotyledon stage (Herridge 1977); at stage V2 (fully developed trifoliolate leaf at node above the unifoliolate nodes), all pots were thinned to four seedlings per pot. The composition of the nutrient solu-

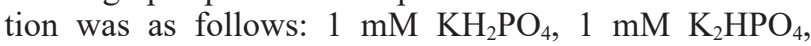
$2 \mathrm{mM} \mathrm{MgSO}_{4} \cdot 7 \mathrm{H}_{2} \mathrm{O}, 1.5 \mathrm{mM} \mathrm{KCl}, 2.5 \mathrm{mM} \mathrm{CaCl}_{2} \cdot 2 \mathrm{H}_{2} \mathrm{O}$, $34.8 \mathrm{mg}$ (Fe(III)-EDTA) $\mathrm{L}^{-1}, 2.86 \mathrm{mg}\left(\mathrm{H}_{3} \mathrm{BO}_{3}\right) \mathrm{L}^{-1}, 1.812$ $\operatorname{mg}\left(\mathrm{MnCl}_{2} \cdot 4 \mathrm{H}_{2} \mathrm{O}\right) \quad \mathrm{L}^{-1}, \quad 0.112 \mathrm{mg}\left(\mathrm{ZnCl}_{2}\right) \quad \mathrm{L}^{-1}, \quad 0.052$ $\mathrm{mg}\left(\mathrm{CuCl}_{2} \cdot 2 \mathrm{H}_{2} \mathrm{O}\right) \mathrm{L}^{-1}$, and $0.024 \mathrm{mg}\left(\mathrm{Na}_{2} \mathrm{MoO}_{4} \cdot 2 \mathrm{H}_{2} \mathrm{O}\right) \mathrm{L}^{-1}$.

Treatments: Upon reaching the early grain-filling stage (R5, seed length up to $3 \mathrm{~mm}$ in the $4^{\text {th }}$ leaf pod), samples of the growing soybean plants were placed in four treatment groups: (1) well-watered (WW), i.e., provided with a continuous supply of normal nutrient solution; (2) well-watered + melatonin (WW $+\mathrm{M}$ ), i.e., $100 \mu \mathrm{mol}\left(\right.$ melatonin) $\mathrm{L}^{-1}$ was added to the nutrient solution 1,2 , and $3 \mathrm{~d}$ after the start of treatment; (3) polyethylene glycol (PEG)-induced drought stress, i.e., PEG was added to the nutrient solution and its concentration was kept at $15 \%$ during the treatment; (4) drought stress + melatonin $(\mathrm{PEG}+\mathrm{M})$, i.e., the PEG concentration in the nutrient solution was kept at $15 \%$ during the treatment and $100 \mu$ mol(melatonin) $\mathrm{L}^{-1}$ was added to the nutrient solution 1, 2, and $3 \mathrm{~d}$ after the start of treatment. After $7 \mathrm{~d}$ of continuous treatment, all treatment groups were returned to a normal nutrient supply. At the same time, a sample of the soybean plants with similar growth was selected to repeat the above drought stress and melatonin treatments: in all, five treatments stage were completed from the beginning of grain filling (R5) to the early maturity stage (R7), as shown in Fig. 2.

Leaf gas exchange: Net photosynthetic rate $\left(P_{\mathrm{N}}\right)$, transpiration rate $(E)$, stomatal conductance $\left(g_{\mathrm{s}}\right)$, and intercellular $\mathrm{CO}_{2}$ concentration $\left(C_{\mathrm{i}}\right)$ of the $4^{\text {th }}$ fully unfolded functional leaf from the main stem of the soybean plants were measured using a $L i-6400$ portable photosynthetic assay system ( $L i-6400$, LICOR, Lincoln, NE, USA). Wateruse efficiency, $\mathrm{WUE}=P_{\mathrm{N}} / E$, and stomatal limitation, $\mathrm{L}_{\mathrm{s}}=$ $1-\left(C_{\mathrm{i}} / C_{a}\right)$, were calculated. Light intensity was 1,200 $\mu \mathrm{mol}\left(\right.$ photon) $\mathrm{m}^{-2} \mathrm{~s}^{-1}, \mathrm{CO}_{2}$ supply concentration was 400 $\mu \mathrm{mol}\left(\mathrm{CO}_{2}\right) \mathrm{mol}^{-1}$, leaf temperature was $25^{\circ} \mathrm{C}$, relative humidity was approxi-mately $25 \%$. Each treatment had five replicates. 

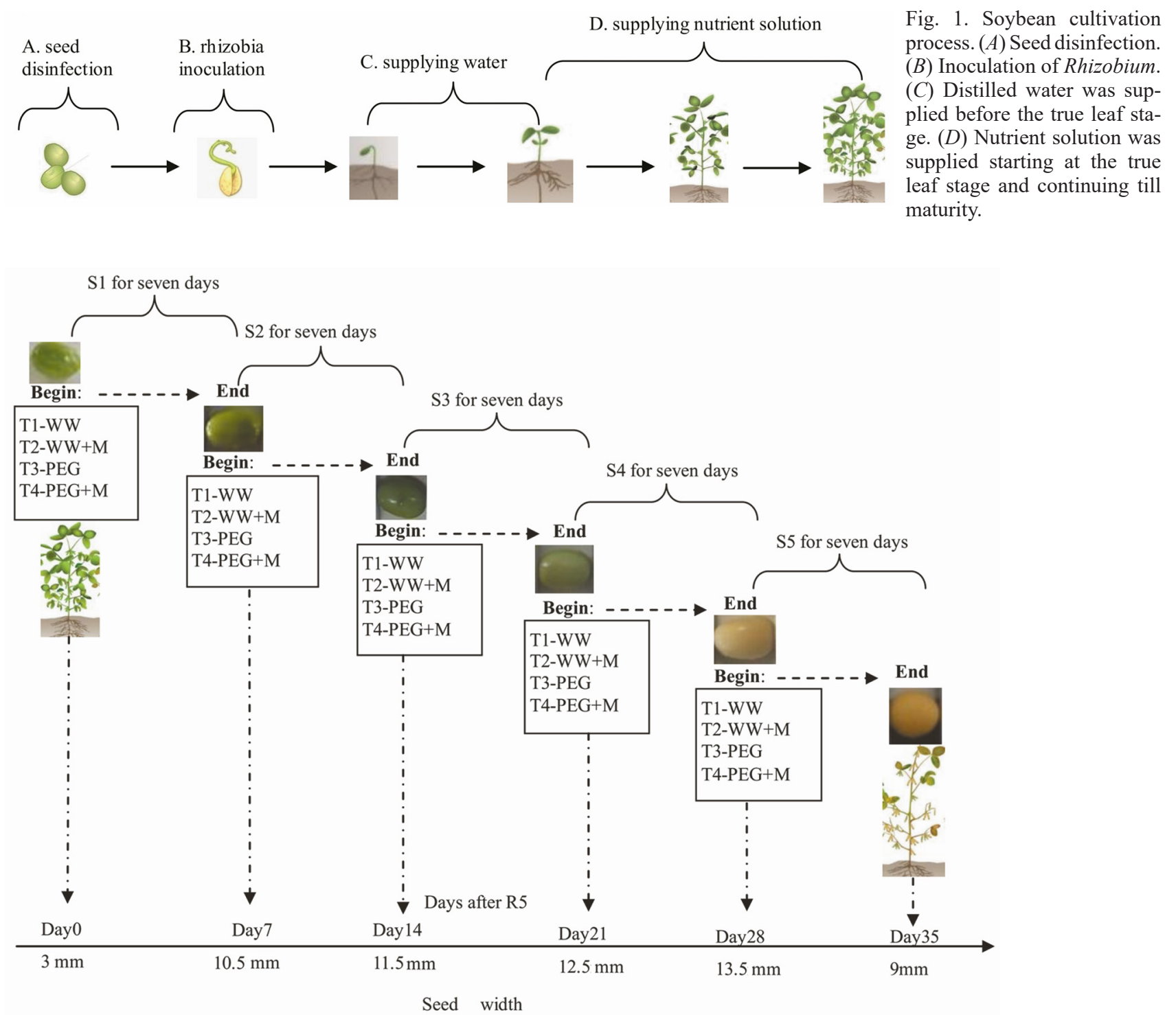

Fig. 2. Experimental procedure. The initiation of the seed-filling stage was recorded as day 0, S1 included days 1-7; S2 included days 7-14; S3 included days 14-21; S4 included days 21-28; and S5 included days 28-35. The seed lengths on days 1, 7, 14, 21, 28, and 35 were $3,10.5,11.5,12.5,13.5$, and $9 \mathrm{~mm}$, respectively. WW - well-watered; $\mathrm{WW}+\mathrm{M}$ - well-watered + melatonin; PEG - PEG-induced drought stress; PEG + M - PEG-induced drought stress + melatonin. All treatment groups were continuously treated for $7 \mathrm{~d}$.

Chl content: A portable Chl content analyzer (SPAD-502 Plus, Konica Minolta, Japan) was used to measure SPAD value of the $4^{\text {th }}$ leaf of each treated soybean plant, each treatment had five replicates.

Determination of antioxidant enzyme activity: The activity of superoxide dismutase SOD (EC 1.15.1.1) activity was determined from $0.2 \mathrm{~g}$ of fresh leaves ground to a homogenate with $5 \mathrm{ml}$ of $50 \mathrm{mmol} \mathrm{L}^{-1}$ phosphate buffer ( $\mathrm{pH}$ 7.8) and centrifuged in a 10-ml centrifuge tube. The supernatant was used as the enzyme extract. Reaction mixture ontained: $14.5 \mathrm{mM}$ methionine (Met) solution, $3 \mathrm{mM}$ EDTA- $\mathrm{Na}_{2}$ solution, $2.25 \mathrm{mM}$ nitroblue tetrazolium (NBT) solution, $60 \mu \mathrm{M}$ riboflavin solution, ratio: $27: 1: 1: 1$. Next, $2.9 \mathrm{ml}$ of the reaction mixture and $0.1 \mathrm{ml}$ of the enzyme extract were added to the tube. The control used $0.1 \mathrm{ml}$ of PBS instead of the enzyme extract. One was treated in the dark with tin foil for control zero adjustment and the other was used for measurement of optical density $\left(O D_{\max }\right)$. The tubes were placed in an illuminated incubator and reacted under illumination for $20 \mathrm{~min}$ at $25^{\circ} \mathrm{C}$. Colorimetric estimation was performed at $560 \mathrm{~nm}$ with a spectrophotometer $(U-2000$, Hitachi Instruments, Tokyo, Japan). SOD activity was calculated in $\left[\mathrm{U} \mathrm{g}^{-1}(\mathrm{FM})\right]=\left[\left(\mathrm{OD}_{\max }-\mathrm{OD}_{560}\right) \times\right.$ total volume of enzyme extract $(\mathrm{ml})] /\left[0.5 \times \mathrm{OD}_{\max } \times \mathrm{FM}(\mathrm{g}) \times\right.$ volume of enzyme solution taken during measurement (ml)] (Beauchamp et al. 1973). POD (EC 1. 11. 1. 7) activity was determined using the same enzyme extract used for SOD. Reaction mixture contained $50 \mathrm{ml}$ of $0.2 \mathrm{~mol} \mathrm{~L}^{-1}$ phosphate buffer (pH 6.0), $28 \mu \mathrm{l}$ of guaiacol, $19 \mu \mathrm{l}$ of $30 \% \mathrm{H}_{2} \mathrm{O}_{2}$. Next, $3 \mathrm{ml}$ of reaction mixture was added $40 \mu$ of enzyme extract and 
the absorbance was read once at $470 \mathrm{~nm}$ wavelength in the next $30 \mathrm{~s}$. POD activity was calculated as $\left[\mathrm{U} \mathrm{g}^{-1}(\mathrm{FM})\right]=$ [change in optical density value within $30 \mathrm{~s}$ of the reaction $\times$ total volume of enzyme extract $(\mathrm{ml})] /[\operatorname{sample} \mathrm{FM}(\mathrm{g}) \times$ volume of enzyme solution used in measurement $(\mathrm{ml}) \times$ $0.01 \times$ reaction time $(\mathrm{min})]$ (Rao et al. 1996). CAT $(\mathrm{EC}$ 1.11.1.6) activity was determined in the same enzyme solution used for SOD. Reaction mixture consisted of

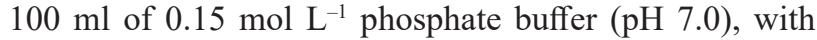
$0.05 \mathrm{ml}$ of $30 \% \mathrm{H}_{2} \mathrm{O}_{2}$. Next, $2.9 \mathrm{ml}$ of the reaction mixture was pipetted, and $0.1 \mathrm{ml}$ of the enzyme extract was added and read every $30 \mathrm{~s}$ at $240 \mathrm{~nm}$. CAT activity was calculated as $\left[\mathrm{U} \mathrm{g}^{-1}(\mathrm{FM})\right]=[$ change in optical density value during $30 \mathrm{~s}$ reaction $\times$ total volume of enzyme extract $(\mathrm{ml})] /$ [sample fresh mass $(\mathrm{g}) \times$ enzyme solution volume $(\mathrm{ml})$ $\times 0.01 \times$ reaction time $(\mathrm{min})]$ (Hamurcu et al. 2013). APX (EC 1. 11. 1. 11) activity was examined in the same enzyme solution used for SOD; $0.1 \mathrm{ml}$ of enzyme solution was added to $2.6 \mathrm{ml}$ of PBS containing $0.1 \mathrm{mM}$ EDTA-Na ( $\left.0.05 \mathrm{~mol} \mathrm{~L}^{-1}, \mathrm{pH} 7.0\right)$, followed by addition of $0.15 \mathrm{ml}$ of $5 \mathrm{mM}$ ascorbic acid, and finally, $0.15 \mathrm{ml}$ of $20 \mathrm{mM} \mathrm{H}_{2} \mathrm{O}_{2}$ was added. Absorbance was read every $30 \mathrm{~s}$ at a wavelength of $290 \mathrm{~nm}$. APX enzyme activity was calculated as $\left[\mathrm{U} \mathrm{g}^{-1}(\mathrm{FM})\right]=[$ change in optical density value during 30 $\mathrm{s}$ reaction $\times$ total volume of enzyme extract $(\mathrm{ml})] /[$ sample FM $(\mathrm{g}) \times$ enzyme solution volume $(\mathrm{ml}) \times 0.01 \times$ reaction time (min)] (Nakano et al. 1981). Each treatment had five replicates.

Osmoregulatory substance contents and membrane lipid peroxidation: The content of soluble protein was determined in the same enzyme extract used for SOD. Next, $1 \mathrm{ml}$ of extract was mixed with $5 \mathrm{ml}$ of Coomassie Brilliant Blue solution and allowed to react for $2 \mathrm{~min}$ and then subjected to colorimetric estimation at $595 \mathrm{~nm}$. A standard curve was prepared with $0-100 \mu \mathrm{g}$ bovine serum albumin. Protein content was calculated as $\left[\mathrm{mg} \mathrm{g}^{-1}\right]$ $=[$ protein content $(\mu \mathrm{g})$ from the standard curve $\times$ total volume of extract $(\mathrm{ml})] /[$ sample fresh mass $(\mathrm{g}) \times$ volume of extract used in the measurement $(\mathrm{ml}) \times 1,000]$ (Arora et al. 1994). Soluble sugar content was determined using the filtrate of $0.20 \mathrm{~g}$ leaves added to $100 \mathrm{ml}$ of distilled water in a $100^{\circ} \mathrm{C}$ water bath for $20 \mathrm{~min}$. Next, $1 \mathrm{ml}$ of the extract plus anthrone reagent $5 \mathrm{ml}$, was subjected to colorimetric determination at $620 \mathrm{~nm}$ and a standard curve was prepared with $0-100 \mu \mathrm{g}$ of glucose. Soluble sugar content was calculated as $\left[\mathrm{mg} \mathrm{g}^{-1}\right]=$ [amount of sugar found in the standard curve $(\mu \mathrm{g}) \times$ volume of extract $(\mathrm{ml}) \times$ dilution factor $] /[$ volume of sample solution $(\mathrm{ml})$ $\times$ sample mass $(\mathrm{g}) \times 1,000]$ (Fairbairn et al. 1953), with measurement of the relative electrical conductivity as a reference (Dionisio-Sese et al. 1998). The $4^{\text {th }}$ functional leaf of each treatment was selected; the surface of the leaf was rinsed with deionized water and quickly dried with filter paper. A sample of $0.20 \mathrm{~g}$ of accurately weighed leaf was placed into a test tube with $20 \mathrm{ml}$ of deionized water, and the conductivity value (R1) was measured after $12 \mathrm{~h}$. The test tube was then placed in a boiling water bath for $20 \mathrm{~min}$, and the conductivity (R2) was measured after cooling to room temperature. Relative conductivity was calculated according to the formula: relative conductivity [\%] = $\mathrm{R} 1 / \mathrm{R} 2 \times 100$. Each treatment was repeated five times.

Malondialdehyde (MDA) content was determined using thiobarbituric acid (Kumar and Knowles 1993) and proline content was determined using acidic ninhydrin colorimetry (Nazar et al. 2015). Superoxide anion production rate was determined as follows: $0.5 \mathrm{~g}$ of the leaf was ground into $10 \mathrm{ml}$ of pre-chilled PBS ( $\mathrm{pH} 7.8$ ), each homogenate was centrifuged at $13,000 \times g$ for $20 \mathrm{~min}$ at $4^{\circ} \mathrm{C}$. The supernatant was obtained for the following analysis: $0.5 \mathrm{ml}$ of the supernatant was added to $0.5 \mathrm{ml}$ of PBS and $1 \mathrm{ml}$ of $10 \mathrm{mmol} \mathrm{L}-1$ hydroxylamine hydrochloride. After $1 \mathrm{~h}, 2 \mathrm{ml}$ of ether and $1 \mathrm{ml}$ of $7 \mathrm{mM} \alpha$-naphthylamine were added at $4^{\circ} \mathrm{C}$, followed by centrifugation at $3,000 \times g$ for $20 \mathrm{~min}$. The absorbance was measured at $530 \mathrm{~nm}$ by spectrophotometer (U-2000, Hitachi Instruments, Tokyo, Japan) using $0.5 \mathrm{ml}$ of PBS as a reference (Ke et al. 2007). Each treatment was repeated five times.

Determination of RWC: Leaf RWC was determined by the dry weighing method. The $4^{\text {th }}$ functional leaves from the main stems were divided into two equal masses, and the fresh mass (FM) was measured. One portion was immersed in deionized water for $12 \mathrm{~h}$ and the turgid mass (TM) was measured; the other portion was placed in an oven at $80^{\circ} \mathrm{C}$ and dried for $48 \mathrm{~h}$ until the mass became

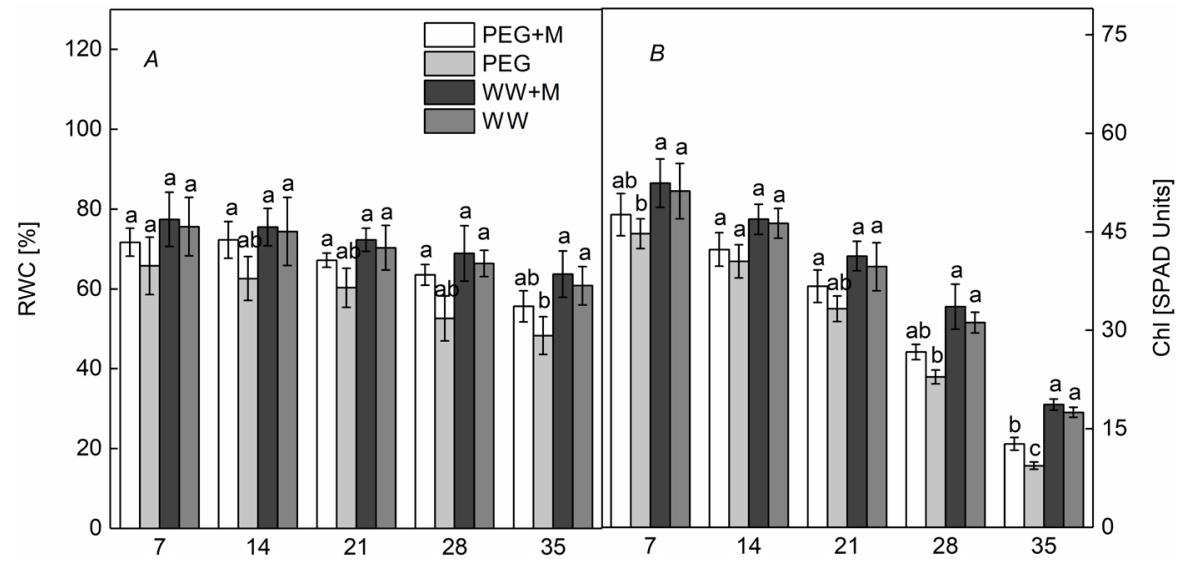

Fig. 3. Effect of normal water supply $(\mathrm{W}+\mathrm{W})$, normal water supply + melatonin $(\mathrm{WW}+\mathrm{M})$, PEG-induced drought stress (PEG), and PEG-induced drought stress + melatonin $(\mathrm{PEG}+\mathrm{M})$ treatment on RWC $(A)$ and chlorophyll content $(B)$ of the $4^{\text {th }}$ leaf at different developmental stages. Data represent means $\pm \mathrm{SD}, n=5$. Different lowercase letters indicate significant differences according to Duncan's multiple range test $(P<0.05)$. 


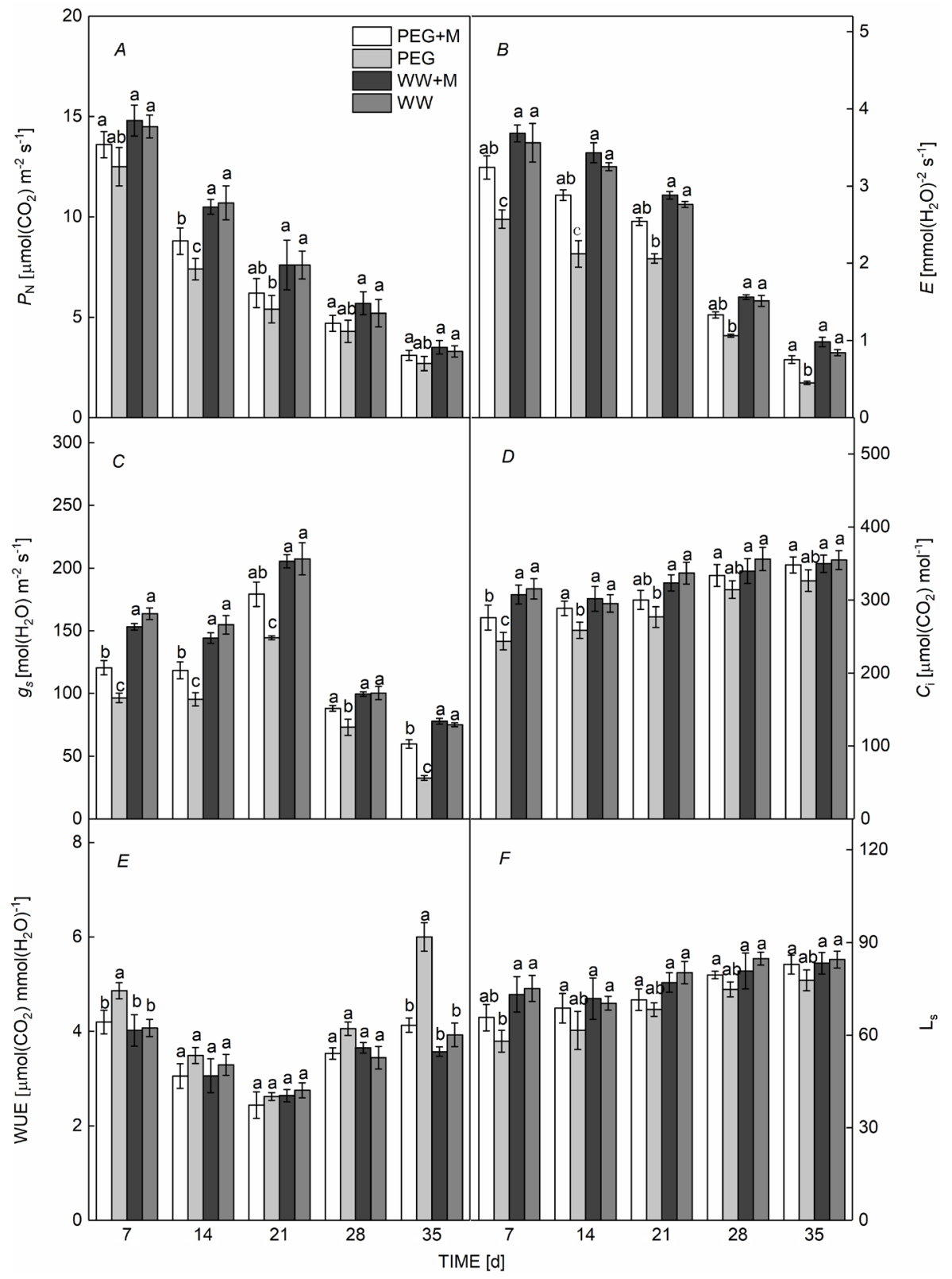

Fig. 4. Effect of normal water supply (WW), normal water supply + melatonin (WW + M), PEG-induced drought stress (PEG), and drought stress + melatonin $(\mathrm{PEG}+\mathrm{M})$ treatment on net photosynthetic rate $\left(P_{\mathrm{N}}\right)(A)$, transpiration rate $(E)(B)$, stomatal conductance $\left(g_{\mathrm{s}}\right)(C)$, intercellular $\mathrm{CO}_{2}$ concentration $\left(C_{\mathrm{i}}\right)(D)$, water-use efficiency (WUE) $(E)$, and stomatal limitation value $\left(\mathrm{L}_{\mathrm{s}}\right)(F)$ of the $4^{\text {th }}$ leaf at different developmental stages. Data represent means $\pm \mathrm{SD}$, $n=5$. Different lowercase letters mean significant differences according to Duncan's multiple range test $(P<0.05)$.

constant and was recorded as dry mass (DM). According to the following formula, leaf RWC $[\%]=(\mathrm{FM}-\mathrm{DM}) /$ $(\mathrm{TM}-\mathrm{DM}) \times 100$. Each treatment was repeated five times.

Seed growth-related indicators and yield: The $4^{\text {th }}$ seed in each treatment group was measured using Vernier calipers. The fresh mass and dry mass were measured. After the soybeans were fully matured, 20 plants from each treatment were weighed using a balance for 100-seed mass and seed mass per plant, and the number of seeds per plant was counted.

Statistical analysis: Data were statistically analyzed and plotted using Origin 2017 software. One-way analysis of variance (ANOVA) was performed using SPSS 20.0.

\section{Results}

Effect of melatonin on leaf RWC and Chl content: Compared with a normal water supply, drought stress (PEG) reduced leaf RWC (Fig. 3A). Under drought stress, exogenous melatonin (PEG $+\mathrm{M})$ increased leaf RWC to a certain extent but this did not reach significant levels. Compared with a normal water supply, drought stress (PEG) reduced the leaf Chl content, which reached a significant level only on day 35 , when it was, on average, $18.2 \%$ lower than that in controls (Fig. $3 B$ ). Under drought stress, exogenous melatonin $(\mathrm{PEG}+\mathrm{M})$ increased the leaf Chl content to a certain extent, but this only reached a significant level on day 35 , with an average increase of $13.3 \%$. 

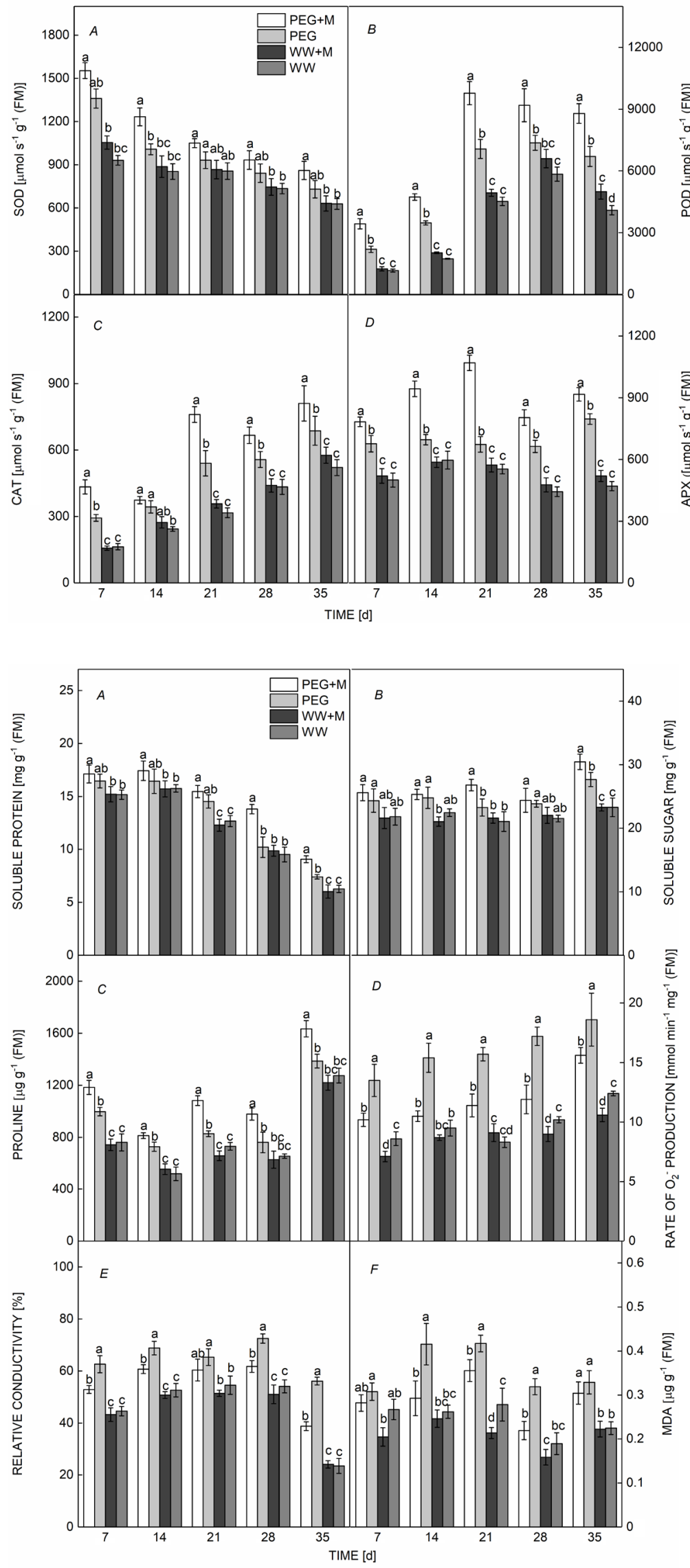

Fig. 5. Effect of normal water supply $(\mathrm{W}+\mathrm{W})$, normal water supply + melatonin $(\mathrm{WW}+\mathrm{M})$, PEG-induced drought stress (PEG), and drought stress + melatonin $(\mathrm{PEG}+\mathrm{M})$ treatment on superoxide dismutase (SOD) $(A)$, peroxidase (POD) $(B)$, catalase (CAT) $(C)$, and ascorbate peroxidase $(\mathrm{APX})(D)$ activity of $4^{\text {th }}$ leaf at different developmental stages. Data represent means $\pm \mathrm{SD}, n=5$. Different lowercase letters indicate significant differences according to Duncan's multiple range test $(P<0.05)$.

Fig. 6. Effect of normal water supply $(\mathrm{W}+\mathrm{W})$, normal water supply + melatonin (WW $+\mathrm{M})$, PEG-induced drought stress (PEG), and drought stress + melatonin $(\mathrm{PEG}+\mathrm{M})$ treatment on soluble protein $(A)$, soluble sugar $(B)$, proline $(C)$, rate of $\mathrm{O}_{2}^{-}$production $(D)$, relative conductivity $(E)$, and malondialdehyde (MDA) $(F)$ activity in the $4^{\text {th }}$ leaf at different developmental stages. Data represent means $\pm \mathrm{SD}, n=5$. Different lowercase letters indicate significant differences according to Duncan's multiple range test $(P<0.05)$. 
Table 1. Effect of normal water supply (WW), normal water supply + melatonin (WW + M), PEG-induced drought stress (PEG), and drought stress + melatonin $(\mathrm{PEG}+\mathrm{M})$ treatment on seed length, and seed fresh and dry mass at different developmental stages. Data represent means $\pm \mathrm{SD}, n=20$. Different lowercase letters indicate significant differences according to Duncan's multiple range test $(P<0.05)$.

\begin{tabular}{lllllll}
\hline Parameter & Treatment & \multicolumn{2}{l}{ Seed development stage [d] } & & \\
& & 7 & 14 & 21 & 28 & 35 \\
\hline Length [mm] & PEG + M & $9.99 \pm 0.44^{\mathrm{a}}$ & $11.58 \pm 0.35^{\mathrm{a}}$ & $11.96 \pm 0.15^{\mathrm{a}}$ & $13.21 \pm 0.34^{\mathrm{a}}$ & $9.34 \pm 0.32^{\mathrm{a}}$ \\
& PEG & $10.33 \pm 0.46^{\mathrm{a}}$ & $11.12 \pm 0.17^{\mathrm{a}}$ & $11.28 \pm 0.37^{\mathrm{a}}$ & $12.58 \pm 0.27^{\mathrm{a}}$ & $9.22 \pm 0.27^{\mathrm{a}}$ \\
& WW $+\mathrm{M}$ & $11.08 \pm 0.75^{\mathrm{a}}$ & $11.74 \pm 0.23^{\mathrm{a}}$ & $12.21 \pm 0.28^{\mathrm{a}}$ & $13.15 \pm 0.32^{\mathrm{a}}$ & $9.23 \pm 0.29^{\mathrm{a}}$ \\
& WW & $10.56 \pm 0.25^{\mathrm{a}}$ & $11.57 \pm 0.20^{\mathrm{a}}$ & $12.31 \pm 0.25^{\mathrm{a}}$ & $13.47 \pm 0.28^{\mathrm{a}}$ & $9.37 \pm 0.30^{\mathrm{a}}$ \\
Fresh mass [g] & PEG + M & $0.240 \pm 0.015^{\mathrm{b}}$ & $0.326 \pm 0.017^{\mathrm{ab}}$ & $0.423 \pm 0.018^{\mathrm{b}}$ & $0.608 \pm 0.015^{\mathrm{a}}$ & $0.328 \pm 0.017^{\mathrm{a}}$ \\
& PEG & $0.194 \pm 0.009^{\mathrm{c}}$ & $0.291 \pm 0.015^{\mathrm{b}}$ & $0.412 \pm 0.027^{\mathrm{b}}$ & $0.597 \pm 0.023^{\mathrm{a}}$ & $0.333 \pm 0.005^{\mathrm{a}}$ \\
& WW $+\mathrm{M}$ & $0.271 \pm 0.013^{\mathrm{a}}$ & $0.355 \pm 0.015^{\mathrm{a}}$ & $0.492 \pm 0.024^{\mathrm{a}}$ & $0.626 \pm 0.016^{\mathrm{a}}$ & $0.324 \pm 0.013^{\mathrm{a}}$ \\
& WW & $0.253 \pm 0.012^{\mathrm{a}}$ & $0.341 \pm 0.020^{\mathrm{a}}$ & $0.510 \pm 0.034^{\mathrm{a}}$ & $0.621 \pm 0.033^{\mathrm{a}}$ & $0.333 \pm 0.010^{\mathrm{a}}$ \\
Dry mass [g] & PEG + M & $0.057 \pm 0.004^{\mathrm{b}}$ & $0.107 \pm 0.008^{\mathrm{a}}$ & $0.178 \pm 0.011^{\mathrm{a}}$ & $0.272 \pm 0.005^{\mathrm{a}}$ & $0.243 \pm 0.008^{\mathrm{a}}$ \\
& PEG & $0.050 \pm 0.003^{\mathrm{c}}$ & $0.096 \pm 0.005^{\mathrm{a}}$ & $0.172 \pm 0.007^{\mathrm{a}}$ & $0.275 \pm 0.014^{\mathrm{a}}$ & $0.250 \pm 0.006^{\mathrm{a}}$ \\
& WW $+\mathrm{M}$ & $0.061 \pm 0.004^{\mathrm{a}}$ & $0.095 \pm 0.004^{\mathrm{a}}$ & $0.196 \pm 0.007^{\mathrm{a}}$ & $0.284 \pm 0.012^{\mathrm{a}}$ & $0.254 \pm 0.003^{\mathrm{a}}$ \\
& WW & $0.067 \pm 0.006^{\mathrm{a}}$ & $0.108 \pm 0.002^{\mathrm{a}}$ & $0.207 \pm 0.004^{\mathrm{a}}$ & $0.278 \pm 0.010^{\mathrm{a}}$ & $0.257 \pm 0.002^{\mathrm{a}}$ \\
\hline
\end{tabular}

Table 2. Effect of normal water supply (WW), normal water supply + melatonin (WW + M), PEG-induced drought stress (PEG), and drought stress + melatonin $(\mathrm{PEG}+\mathrm{M})$ treatment on 100-seed mass, individual seed mass, and seed number per plant at different developmental stages. Data represent means $\pm \mathrm{SD}, n=20$. Different lowercase letters indicate significant differences according to Duncan's multiple range test $(P<0.05)$.

\begin{tabular}{|c|c|c|c|c|c|c|}
\hline \multirow[t]{2}{*}{ Parameter } & \multirow[t]{2}{*}{ Treatment } & \multicolumn{5}{|c|}{ Seed development stage $[\mathrm{d}]$} \\
\hline & & 7 & 14 & 21 & 28 & 35 \\
\hline \multirow[t]{4}{*}{ Seed number } & $\mathrm{PEG}+\mathrm{M}$ & $31.09 \pm 2.04^{\mathrm{a}}$ & $29.33 \pm 2.04^{\mathrm{a}}$ & $29.39 \pm 2.15^{\mathrm{a}}$ & $30.63 \pm 1.88^{\mathrm{a}}$ & $30.49 \pm 1.75^{\mathrm{a}}$ \\
\hline & PEG & $30.48 \pm 1.65^{\mathrm{a}}$ & $29.48 \pm 1.59^{\mathrm{a}}$ & $29.65 \pm 1.78^{\mathrm{a}}$ & $30.67 \pm 2.09^{\mathrm{a}}$ & $31.80 \pm 2.18^{\mathrm{a}}$ \\
\hline & $\mathrm{WW}+\mathrm{M}$ & $31.24 \pm 3.28^{\mathrm{a}}$ & $30.85 \pm 1.32^{\mathrm{a}}$ & $29.81 \pm 1.93^{\mathrm{a}}$ & $29.95 \pm 3.42^{\mathrm{a}}$ & $30.67 \pm 1.61^{\mathrm{a}}$ \\
\hline & WW & $31.47 \pm 1.75^{\mathrm{a}}$ & $31.47 \pm 1.75^{\mathrm{a}}$ & $31.47 \pm 1.75^{\mathrm{a}}$ & $31.47 \pm 1.75^{\mathrm{a}}$ & $31.47 \pm 1.75^{\mathrm{a}}$ \\
\hline \multirow[t]{4}{*}{100 -grain mass } & $\mathrm{PEG}+\mathrm{M}$ & $24.35 \pm 0.14^{\mathrm{b}}$ & $25.77 \pm 0.33^{\mathrm{b}}$ & $25.99 \pm 0.36^{\mathrm{a}}$ & $26.67 \pm 2.24^{\mathrm{a}}$ & $26.31 \pm 0.39^{\mathrm{a}}$ \\
\hline & PEG & $22.83 \pm 0.16^{\mathrm{c}}$ & $23.62 \pm 0.05^{\mathrm{b}}$ & $24.72 \pm 0.57^{\mathrm{ab}}$ & $26.02 \pm 0.46^{\mathrm{a}}$ & $26.44 \pm 1.24^{\mathrm{a}}$ \\
\hline & $\mathrm{WW}+\mathrm{M}$ & $27.07 \pm 0.15^{\mathrm{a}}$ & $26.74 \pm 0.07^{\mathrm{a}}$ & $26.34 \pm 0.96^{\mathrm{a}}$ & $26.95 \pm 0.07^{\mathrm{a}}$ & $26.75 \pm 0.47^{\mathrm{a}}$ \\
\hline & WW & $26.73 \pm 0.23^{\mathrm{a}}$ & $26.73 \pm 0.23^{\mathrm{a}}$ & $26.73 \pm 0.23^{\mathrm{a}}$ & $26.73 \pm 0.23^{\mathrm{a}}$ & $26.73 \pm 0.23^{\mathrm{a}}$ \\
\hline \multirow[t]{4}{*}{ Single seed mass } & $\mathrm{PEG}+\mathrm{M}$ & $7.41 \pm 0.13^{b}$ & $7.61 \pm 0.25^{\mathrm{b}}$ & $8.51 \pm 0.27^{\mathrm{a}}$ & $8.41 \pm 0.13^{\mathrm{a}}$ & $8.67 \pm 0.25^{\mathrm{a}}$ \\
\hline & PEG & $6.74 \pm 0.06^{\mathrm{c}}$ & $7.17 \pm 0.24^{b}$ & $8.03 \pm 0.07^{\mathrm{ab}}$ & $8.31 \pm 0.13^{\mathrm{a}}$ & $8.62 \pm 0.18_{a}$ \\
\hline & $\mathrm{WW}+\mathrm{M}$ & $8.51 \pm 0.11^{\mathrm{a}}$ & $8.58 \pm 0.18^{\mathrm{a}}$ & $8.63 \pm 0.12^{\mathrm{a}}$ & $8.47 \pm 0.31^{\mathrm{a}}$ & $8.68 \pm 0.33^{\mathrm{a}}$ \\
\hline & WW & $8.35 \pm 0.44^{\mathrm{a}}$ & $8.35 \pm 0.44^{\mathrm{a}}$ & $8.35 \pm 0.44^{\mathrm{a}}$ & $8.35 \pm 0.44^{\mathrm{a}}$ & $8.35 \pm 0.44^{\mathrm{a}}$ \\
\hline
\end{tabular}

Effect of melatonin on photosynthesis: Compared with a normal water supply, PEG-induced drought stress reduced $P_{\mathrm{N}}$ (Fig. 4A), $E$ (Fig. 4B), $g_{\mathrm{s}}$ (Fig. 4C), $C_{\mathrm{i}}$ (Fig. 4D), and $\mathrm{L}_{\mathrm{s}}$ (Fig. 4E), while it improved WUE (Fig. 4F). Under drought stress, exogenous melatonin $(\mathrm{PEG}+\mathrm{M})$ increased $P_{\mathrm{N}}, C_{\mathrm{i}}, g_{\mathrm{s}}, E$, and $\mathrm{L}_{\mathrm{s}}$ to a certain extent, whereas it reduced WUE.

Effects of melatonin on antioxidant enzyme activity: Compared with normal water supply, PEG-induced drought stress increased antioxidant enzyme activity. On average, SOD activity increased by $7.2 \%$ in the five developmental stages under study, as shown in Fig. $5 \mathrm{~A}$. POD increased by $70.2 \%$ (Fig. $5 B$ ), APX increased by $38.4 \%$ (Fig. $5 D$ ), and CAT increased by $47.5 \%$ (Fig. $5 C$ ).
Under drought stress, addition of exogenous melatonin $(\mathrm{PEG}+\mathrm{M})$ increased the activity of antioxidant enzymes to a certain extent. Among them, SOD increased by $5.8 \%$ on average during five stages, POD increased by $37.2 \%$, APX increased by $29.2 \%$, and CAT increased by $26.8 \%$.

Effects of melatonin on osmoregulatory substance content and membrane lipid peroxidation in leaves: Compared with a normal water supply, PEG-induced drought stress increased soluble protein (Fig. 6A), soluble sugar (Fig. 6B), and proline content (Fig. 6C); concomitantly, it increased $\mathrm{O}_{2}^{-}$production rate (Fig. $6 D$ ), relative conductivity (Fig. 6E), and MDA content (Fig. 6F). Under PEG-induced drought stress, exogenous melatonin $(\mathrm{PEG}+\mathrm{M})$ increased soluble sugar, soluble protein, and 
proline contents to some degree, while it reduced the rate of $\mathrm{O}_{2}^{-}$production, relative conductivity, and MDA content.

Effects of melatonin on soybean seed development: As Table 1 shows, there was no significant difference in PEG-induced drought stress effects on seed length during the seed development, although the seed FM was significantly lower on days 7,14 , and 21 , compared to the corresponding values on days 28 and 35 . However, seed DM was significantly different only on day 7. Under PEGinduced drought stress, addition of exogenous melatonin $(\mathrm{PEG}+\mathrm{M})$ produced no significant difference in seed length, and seed FM and DM were significantly lower only on day 7 .

Effects of melatonin on soybean yield: Table 2 shows that drought stress (PEG) significantly reduced 100-seed mass and seed mass per plant on days 7 and 14; 100-seed mass decreased by 14.6 and $9.1 \%$, respectively, while seed mass per plant decreased by 19.3 and $14.5 \%$, respectively. Under PEG-induced drought stress, addition of exogenous melatonin (PEG $+\mathrm{M})$ significantly increased 100-seed mass and seed mass per plant on day 7 (6.7 and 9.9\%, respectively).

\section{Discussion}

Soybean is known to be sensitive to water deficit, which first affects the physiological and biochemical processes in soybean and then plant morphology ( $\operatorname{Rad}$ et al. 2012). Drought stress causes plants to accumulate large amounts of ROS and reduces Chl contents ( $\mathrm{Li}$ et al. 2012). Previous studies have shown that exogenous melatonin can effectively alleviate the adverse effects of drought on the Chl content of cucumber and maize, and increase the photosynthetic rate (Wang et al. 2016, Ye et al. 2016). In the present study, melatonin increased the Chl content of soybean leaves during different stages of seed development under drought stress, which in turn increased light absorption and transformation efficiency. Moreover, melatonin maintained photosynthetic gasexchange parameters and photosynthetic rate of soybean plants at relatively high levels under drought stress, which, in turn, kept the photosynthetic electron transport rate and assimilation capability at relatively high level. These findings are consistent with results reported previously on maize (Jun et al. 2016) and tomato (Liu et al. 2015). Higher WUE under drought stress is an important strategy to enhance plant drought resistance (Zhang et al. 2010). However, our results showed that exogenous melatonin actually reduced soybean WUE under drought stress. This may be explained because exogenous melatonin increased the extent of stomatal closure and the content of osmoregulatory substances in order to maintain leaf-cell turgor at a relatively high level, which in turn, increased the transpiration rate.

Drought stress might induce an imbalance in ROS metabolism whereby ROS content in plant cells may surge, thus causing membrane lipid peroxidation and cell membrane damage (Gong et al. 2005). Plants scavenge intracellular free radicals through antioxidant enzymes (de Souza et al. 2014). Drought stress causes upregulation of gene expression of ROS scavenging enzymes (e.g., SOD and POD) (Takahashi and Murata 2008, Schmutz et al. 2010), and increases osmoregulatory substance content in leaf tissues. Our study found that drought stress led to increased SOD, POD, APX, and CAT activities, which is consistent with previous results (Schmutz et al. 2010, Tóth et al. 2011). Moreover, melatonin supplementation under drought stress increased the activity of protective enzymes in soybean leaves and reduced the rate of $\mathrm{O}_{2}{ }^{-}$ production. The increase in protective enzyme activity and osmoregulatory substances not only helped remove excess free radicals and hinder water evaporation (Liu et al. 2015, Ye et al. 2016), but it also decreased the level of membrane lipid peroxidation, thereby limiting the increase in MDA content and in relative conductivity caused by drought stress.

Drought stress affects the accumulation and partitioning of dry matter, which might decrease the yield (FugantiPagliarini et al. 2017). Moreover, the occurrence of drought at different seed developmental stages in soybean might also have different effects on the yield. The present study showed that drought stress had the greatest impact on dry matter accumulation in the early stages of seed development (0-7 $\mathrm{d}$ and 7-14 $\mathrm{d}$ after the beginning of the grain filling), and ultimately reduced 100 -seed mass at harvest. Dry matter accumulation, 100-seed mass, and seed mass per plant were higher in the $P E G+M$ treatment than that in the PEG-induced drought treatment. These beneficial effects were particularly evident at the early stage of seed development.

In conclusion, drought inhibited photosynthesis and increased WUE at different seed developmental stages, while melatonin supplementation improved osmotic regulation and ROS scavenging, which in turn, alleviated the adverse effects of drought stress on photosynthesis, and restored seed growth and yield.

\section{References}

Arora R., Wisniewski M.E.: Cold acclimation in genetically related (sibling) deciduous and evergreen peach. II. A $60-\mathrm{kDa}$ bark protein in cold-acclimated tissue of peach is heatstable and related to the dehydrin family of proteins. - Plant Physiol. 105: 95-101, 1994.

Beauchamp C.O., Fridovich I.: Isozymes of superoxide dismutase from wheat germ. - BBA-Protein Struct. M. 317: 50-64, 1973.

Chen Q., Qi W.B., Reiter R.J. et al.: Exogenously applied melatonin stimulates root growth and raises endogenous indoleacetic acid in roots of etiolated seedlings of Brassica juncea. - J. Plant Physiol. 166: 324-328, 2009.

Dai A.: Increasing drought under global warming in observations and models. - Nat. Clim. Change 3: 52-58, 2013.

de Souza T.C., Magalhães P.C., de Castro E.M. et al.: ABA application to maize hybrids contrasting for drought tolerance: Changes in water parameters and in antioxidant enzyme activity. - Plant Growth Regul. 73: 205-217, 2014.

Dionisio-Sese M.L., Tobita S.: Antioxidant responses of rice seedlings to salinity stress. - Plant Sci. 135: 1-9, 1998.

Fairbairn N.J.: A modified anthrone reagent. - Chem. Ind. 4: 86, 1953. 
Foyer C.H., Lam H.M., Nguyen H.T. et al.: Neglecting legumes has compromised human health and sustainable food production. - Nat. Plants 2: 16112, 2016.

Fuganti-Pagliarini R., Ferreira L.C., Rodrigues F.A. et al.: Characterization of soybean genetically modified for drought tolerance in field conditions. - Front. Plant Sci. 8: 448-463, 2017.

Gao H., Zhang Z.K., Chai H.K. et al.: Melatonin treatment delays postharvest senescence and regulates reactive oxygen species metabolism in peach fruit. - Postharvest Biol. Tec. 118: 103-110, 2016

Getachew M.: Influence of soil water deficit and phosphorus application on phosphorus uptake and yield of soybean (Glycine $\max$ L.) at Dejen, North-West Ethiopia. - Am. J. Plant Sci. 5: 1889-1906, 2014.

Gong H., Zhu X., Chen K. et al:: Silicon alleviates oxidative damage of wheat plants in pots under drought. - Plant Sci. 169: 313-321, 2005.

Hamurcu M., Sekmen A.H., Turkan I. et al.: Induced anti-oxidant activity in soybean alleviates oxidative stress under moderate boron toxicity. - Plant Growth Regul. 70: 217-226, 2013.

Herridge D.F.: Carbon and Nitrogen Nutrition of Two Annual Legumes. PhD thesis. University of Western Australia, Perth 1977.

Ke D., Sun G.C., Wang Z.X.: Effects of superoxide radicals on ACC synthase activity in chilling-stressed etiolated mungbean seedlings. - Plant Growth Regul. 51: 83-91, 2007.

Kumar G.N.M., Knowles N.R.: Changes in lipid peroxidation and lipolytic and free-radical scavenging enzyme activities during aging and sprouting of potato (Solanum tuberosum) seed-tubers. - Plant Physiol. 102: 115-124, 1993.

Lei Q., Wang L., Tan D.X. et al.: Identification of genes for melatonin synthetic enzymes in 'Red Fuji' apple (Malus domestica Borkh. cv. Red) and their expression and melatonin production during fruit development. - J. Pineal Res. 55: 443-451, 2013.

Li C., Wang P., Wei Z. et al.: The mitigation effects of exogenous melatonin on salinity-induced stress in Malus hupehensis. J. Pineal Res. 53: 298-306, 2012.

Liu J.L., Wang W.X., Wang L.Y., Sun Y.: Exogenous melatonin improves seedling health index and drought tolerance in tomato. - Plant Growth Regul. 77: 317-326, 2015.

Manavalan L.P., Guttikonda S.K., Tran L.S., Nguyen H.T.: Physiological and molecular approaches to improve drought resistance in soybean. - Plant Cell Physiol. 50: 1260-1276, 2009.

Meng J.F., Xu T.F., Wang Z.Z. et al.: The ameliorative effects of exogenous melatonin on grape cuttings under water-deficient stress: Antioxidant metabolites, leaf anatomy, and chloroplast morphology. - J. Pineal Res. 57: 200-212, 2014.

Nakano Y., Asada K.: Hydrogen peroxide is scavenged by ascorbate-specific peroxidase in spinach chloroplasts. - Plant Cell Physiol. 22: 867-880, 1981.

Nazar R., Umar S., Khan N.A., Sareer O.: Salicylic acid supplementation improves photosynthesis and growth in mustard through changes in proline accumulation and ethylene formation under drought stress. - S. Afr. J. Bot. 98: 84-94, 2015.

Ommen O.E., Donnelly A., Vanhoutvin S. et al.: Chlorophyll content of spring wheat flag leaves grown under elevated $\mathrm{CO}_{2}$ concentrations and other environmental stresses within the ESPACE-wheat project. - Eur. J. Agron. 10: 197-203, 1999.

Rad R.N., Kadir M.A., Jaafar H.Z.E., Gement D.C.: Physiological and biochemical relationship under drought stress in wheat (Triticum aestivum). - Afr. J. Biotechnol. 11: 1574-1578, 2012.

Rao M.V., Paliyath G., Ormrod D.P.: Ultraviolet-B- and ozoneinduced biochemical changes in antioxidant enzymes of Arabidopsis thaliana. - Plant Physiol. 110: 125-136, 1996.

Schmutz J., Cannon S.B., Schlueter J. et al.: Genome sequence of the palaeopolyploid soybean. - Nature 463: 178-183, 2010.

Shi H., Reiter R.J., Tan D.X., Chan Z.: INDOLE-3-ACETIC ACID INDUCIBLE 17 positively modulates natural leaf senescence through melatonin-mediated pathway in Arabidopsis. - J. Pineal Res. 58: 26-33, 2015.

Specht J.E., Hume D.J., Kumudini S.V.: Soybean yield potential - A genetic and physiological perspective. - Crop Sci. 39: 1560-1570, 1999.

Sun Q., Zhang N., Wang J. et al.: Melatonin promotes ripening and improves quality of tomato fruit during postharvest life. J. Exp. Bot. 66: 657-668, 2014.

Takahashi. S., Murata. N.: How do environmental stresses accelerate photoinhibition? - Trends Plant Sci. 13: 178-182, 2008.

Tóth S.Z., Nagy V., Puthur J.T. et al.: The physiological role of ascorbate as photosystem II electron donor: Protection against photoinactivation in heat-stressed leaves. - Plant Physiol. 156: 382-392, 2011.

Wang L.Y., Liu J.L., Wang W.X., Sun Y.: Exogenous melatonin improves growth and photosynthetic capacity of cucumber under salinity-induced stress. - Photosynthetica 54: 19-27, 2016.

Wang P., Sun X., Li C. et al.: Long-term exogenous application of melatonin delays drought-induced leaf senescence in apple. J. Pineal Res. 54: 292-302, 2013.

Wei W., Li Q.T., Chu Y.N. et al.: Melatonin enhances plant growth and abiotic stress tolerance in soybean plants. J. Exp. Bot. 66: 695-707, 2014.

Westgate M.E., Peterson C.M.: Flower and pod development in water deficient soybean. - J. Exp. Bot. 258: 109-117, 1993.

Ye J., Wang S.W., Deng X.P. et al.: Melatonin increased maize (Zea mays L.) seedling drought tolerance by alleviating drought-induced photosynthetic inhibition and oxidative damage. - Acta Physiol. Plant. 38: 48, 2016.

Zhang N., Zhao B., Zhang H.J. et al.: Melatonin promotes waterstress tolerance, lateral root formation, and seed germination in cucumber (Cucumis sativus L.). - J. Pineal Res. 54: 15-23, 2013.

Zhang S.Y., Zhang G.C., Gu S.Y. et al.: Critical responses of photosynthetic efficiency of goldspur apple tree to soil water variation in semiarid loess hilly area. - Photosynthetica 48: 589-595, 2010.

(C) The authors. This is an open access article distributed under the terms of the Creative Commons BY-NC-ND Licence. 